\title{
Fault Plane Identification Using Three Components Local Waveforms
}

\author{
Bagus Jaya Santosa \\ Physics Department, Faculty Mathematics and Science, ITS J1. ArifRahman Hakim I, Surabaya, Indonesia \\ Email: bjs@physics.its.ac.id
}

Received December 9, 2012; revised March 12, 2013; accepted April 6, 2013

Copyright (C) 2013 Bagus Jaya Santosa. This is an open access article distributed under the Creative Commons Attribution License, which permits unrestricted use, distribution, and reproduction in any medium, provided the original work is properly cited.

\begin{abstract}
A research has been conducted to estimate earthquake source parameters that occurred on June 3rd, 13th, 18th and 19th, 2008. The data used to determine the parameters of earthquakes source are three components local waveform that are recorded by three MY broadband stations (IPM, KOM and KUM) and PSI, Poseidon. In this research, we report a focal mechanism of events using three components local waveform analysis. The seismogram data are inverted to achieve the earthquake source parameters. Source parameters of earthquakes extracted after the reduction variant of each event are over $56 \%$. To identify the fault plane, the HC-plot method is used.
\end{abstract}

Keywords: 3 Components Local Waveform; Earthquake Source Parameters

\section{Introduction}

Earthquake is a natural phenomenon, in shape of natural shock from earth interior which propagates to the surface. There are three types of earthquake that is commonly known. The first one is tectonic earthquake that has close relation to fault formation, as a direct consequence from slab collision. This type of earthquake usually has a magnitude more than 5 Richter Scale. Vulcanic earthquake is an earthquake that is related to volcano activity. This earthquake can be classified as micro to moderate earthquake, and usually has a magnitude less than 4 Richter Scale. The third type is a collapse that is caused by avalanche which is a minor earthquake. The magnitude of this earthquake is very small that it can not be felt in the surface. It has the shape of tremor and can only be detected by seismometer. Large fault is also one of the earthquake sources. Such as Semangko fault that divides Sumatra Island. The fault is a weak zone that can be easily affected by tectonic earthquake. There are two zones where the earthquake strikes the most in Sumatra, which are: 1) slab subduction zone that is located in West Sumatran ocean which has a potency of causing earthquake with a relatively big magnitude and has a good chance of causing tsunami; 2) Sumatra fault zone known as Semangko (Figure 1). Semangko fault is a very active fault in the land that separate Sumatra Island into two part, spreading out along Bukit Barisan mountain range, from Semangko bay in Sunda strait until Aceh in north. Se- mangko fault is the most active fault in the world. The earthquakes that occur in Java and Sumatra is a geodynamic implication of an active deformation around Sunda (Java) trench $[1,2]$. West Sumatra is the boundary of ocean slab which consists of two faulting systems, which are strike-slip faulting system that rotate toward right direction (dextral) and interface dip-slip subduction which has bigger influence [2]. Slope convergence that points

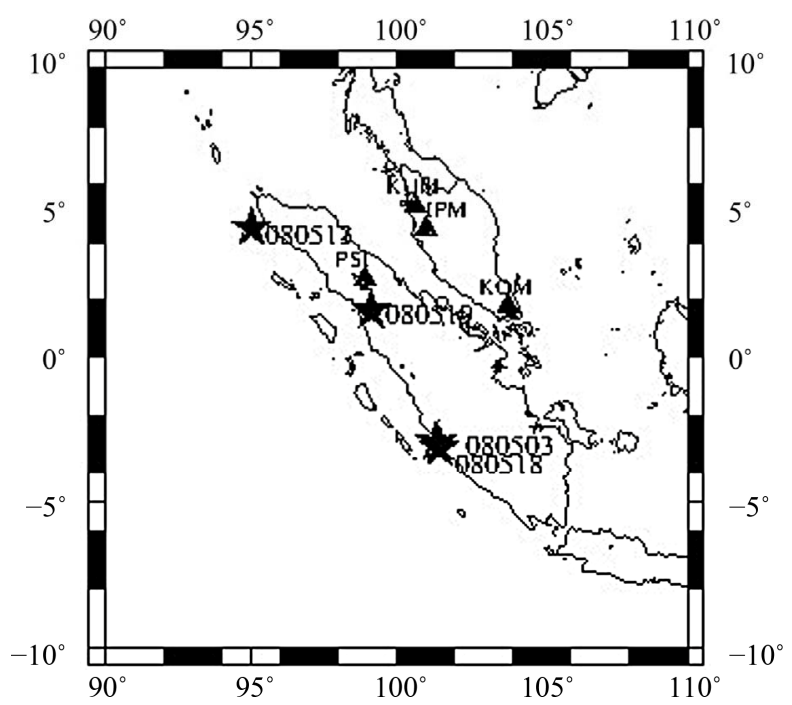

Figure 1. Epicenter position of 03/05/2008, 13/05/2008, 18/ $05 / 2008$ and 19/05/2008 (star) events and 4 stations (IPM, KUM, KOM and PSI) (triangle). 
toward north direction from Indian and Australian slabs is moving toward South East Asia with the velocity of 60 $\mathrm{mm} / \mathrm{yr}$ [3]. Slab convergence is divided into a slip parallel to the trench accomodated by Sumatra fault and perpendicular slip which is accomodated by subduction zone interface [2]. Sumatra fault has caused tens of earthquakes with a magnitude $7 \leq M \leq 7.7$, also several minor events, in the last century. Subduction on India-Australia slab was occured at Sumatra slab boundary with the velocity around $60 \mathrm{~mm} / \mathrm{yr}$ toward $\mathrm{N} 11^{\circ} \mathrm{E}$. Oblique convergence partitioned into trench parallel to slip-mostly accomodated by Sumatra faulting zone and trench perpendicular to slip-mostly accomodated by subduction zone. More detailed map of Sumatra faulting zone (SFZ) shows that Sumatra fault consist of many segments. The influence of the fault segmentation to the dimension of seismic source shows that the dimension for future seismic events also influenced by fault geometry [2]. Understanding the cracks caused by an active fault is the fundamental purpose that has not been achieved in earthquake science. The main reason of the slow development is the data rareness and relevant analysis on how strain accumulate on the region around fault and how does the fault release that accumulated strain [4]. The event on 2008/05/03, 2008/05/13 and $2008 / 05 / 19 / 05$ were occured in the sea and triggered by subduction, while the one that happened on 2008/05/19 was occured in the land and triggered by Semangko fault. Hypocenter, depth and the origin time of four events has been reported by IRIS [5] and Geofon [6], and also the centroid time of three earthquakes from

www.globalcmt.org, as shown in Table 1.

Hypocenter, magnitude moment and origin time of the earthquake that is provided by two seismological institutes have differences, while the 2008/05/03 event is not reported by Global CMT. Only one from these three in-

Table 1. Hypocenter, $M_{w}$ and origin/centroid time of events 2008/05/03, 2008/05/13, 2008/05/18 and 2008/05/19.

\begin{tabular}{ccccccc}
\hline Source & Event & $\begin{array}{c}\text { Origin } \\
\text { Time (UTC) }\end{array}$ & Lat $\left(^{\circ}\right)$ & Lon $\left(^{\circ}\right)$ & $\mathbf{M}_{\mathbf{w}}$ & $\begin{array}{c}\text { Depth } \\
(\mathbf{k m})\end{array}$ \\
\hline \multirow{2}{*}{ IRIS } & $2008 / 05 / 03$ & $03: 53: 35.0$ & -3.0152 & 101.1898 & 5.4 & 51.7 \\
& $2008 / 05 / 13$ & $10: 29: 21.0$ & 4.6634 & 95.1228 & 5.4 & 52.8 \\
& $2008 / 05 / 19$ & $14: 26: 46.0$ & 1.6754 & 99.0534 & 6.0 & 14.8 \\
& $2008 / 05 / 03$ & $03: 53: 37$ & -3.00 & 101.1 & 5.7 & 64 \\
& $2008 / 05 / 13$ & $01: 52: 21$ & 4.80 & 95.10 & 5.6 & 44.0 \\
Geofon & $2008 / 05 / 18$ & $12: 17: 25$ & -3.30 & 101.10 & 5.8 & 51.0 \\
& $2008 / 05 / 19$ & $14: 26: 47$ & 1.70 & 99.0 & 5.9 & 10.0 \\
& $2008 / 05 / 03$ & $3: 53: 37.7$ & -3.28 & 101.09 & 5.6 & 50.4 \\
Global & $2008 / 05 / 13$ & $10: 29: 22.44$ & 4.37 & 95.05 & 5.6 & 50.4 \\
CMT & $2008 / 05 / 18$ & $12: 17: 28.47$ & -3.52 & 101.11 & 5.5 & 50.1 \\
& $2008 / 05 / 19$ & $14: 26: 48.93$ & 1.64 & 99.14 & 5.8 & 16.1 \\
\hline
\end{tabular}

stitutes also provides CMT, which is Global CMT. This institute has analyzed the CMT of these events using teleseismic data (distance between epicenter and stations $>25^{\circ}$ ) the CMT that is provided by seismological institute is also significantly different.

In this article, we present 3 components local waveform analysis (distance between epicenter and stations $\leq 10^{\circ}$ ), that is recorded by three MY network stations and PSI station, with a distance less than $10^{\circ}$ from the epicenter of the earthquakes, to predict the parameters of earthquake sources, and to identify the fault plane of the earthquakes.

\section{Event Locations and MY, PS Network Station}

Earthquake characteristic can be known from the earthquake source parameters. Earthquake source parameters obtained by analysing earthquake data that is well known by the term seismic wave. Seismic wave that is originated from the earthquake source (hypocenter) is recorded by observatory stations installed around the earthquake region. To obtain seismic wave data of both earthquakes, the authors used three components waveform from the local data recorded by three IRIS/Malaysia MY network stations (IPM, KOM dan KUM) and one Poseidon network station as illustrated (Figure 1). The epicentral distance of each station is not more than $10^{\circ}$.

The epicenter distance of 2008/05/03 event with each PSI, KOM, IPM and KUM stations are, $6.06^{\circ}, 5.27^{\circ}$, $7.33^{\circ}$ and $8.16^{\circ}$, respectively.

\section{Three Components Local Waveform Inversion and Fault Plane Determination}

Three components seismogram that was recorded by MY and PS network, will later be inverted using Green function that is calculated iteratively using Wave Number Discretisation method [7]. To calculate Green function, we used 1-D velocity model (Table 2) and the hypocenter of both events obtained from IRIS. This velocity model is a research result [8] that is verified and modified for Sumatra implementation. The first six layer of all the velocity model with its parameters is using Novotny, et al. [8]. While, for the seventh layer along with all of its parameter is a verified and modified result of the author. The modification was based on Santosa [9] research on earth model. The hypocenter used to calculate the Green function is available at IRIS (Table 1), because the three components local waveform data are from IRIS. Next is inverting three components waveform using iteration deconvolution method $[10,11]$. This method is implemented in ISOLA software [12,13] as a numerical simulation program development [14], to obtain earthquake source parameters. The inversion is using frequency band 
between $17.5 \mathrm{mHz}$ and $52.5 \mathrm{mHz}$ for all events. Earthquake source parameters will later be used to de- termine the orientation, fault plane length and width and also slip length of both earthquakes. To determine real fault plane orientation, HC-plot method is used [14].

\section{Earthquake Source Parameters}

Earthquake Source Parameters is used for microzonation and seismic risk treatment [13]. Seismic moment $\left(\mathrm{M}_{0}\right)$, magnitude moment $\left(\mathrm{M}_{\mathrm{w}}\right)$, depth, orientation and fault plane width also slip length is determined for both events. On this analysis, the authors used three components local waveform. Earthquake source parameters can be extracted from mathematical model, if good fitting is achieved between measured and synthetic seismogram. Reduction variant for these events are over $60 \%$. Seismogram fitting, DC values and reduction variant are presented in Figures 2-5.

Based on the analysis, earthquake source parameters for earthquakes event are obtained (Figures 6-9).

To identify the actual fault plane of both faulting plane, HC-plot method is used. The centroid coordinate and the fault plane $\left(\right.$ strike $=314^{\circ} ; \operatorname{dip}=34^{\circ}$ and depth $=32 \mathrm{~km}$ ) for 2008/05/03 event isillustrated in Figure 6, where its reduction variant for this event is $60 \%$. The $2008 / 05 / 13$ event $($ strike $=279 ;$ dip $=29$ and depth $=44.4 \mathrm{~km}$ ) was taken from source parameters of the inversion result on Figure 7, respectively. The centroid coordinate and the fault plane $\left(\right.$ strike $=14^{\circ} ; \operatorname{dip}=50^{\circ}$ and depth $\left.=37 \mathrm{~km}\right)$ for 2008/05/18 event and (strike $=125$; dip $=53$ and depth $=8.7321 \mathrm{~km}$ ) for 2008/05/19 event was taken from source parameters of the inversion result on Figures 8 and 9, respectively. While the hypocenter coordinate for 20080503, 20080513 and 20080518 events are using IRIS data and for 2008/05/19 event is using Geofon data (Table 1). The principal of $\mathrm{H}$ (ypocenter)C(entroid)-plot is putting hypocenter and centroid (the intersection between fault plane 1 and fault plane 2) of the 3 components local waveform inversion (Figures 2 and $\mathbf{3}$ ) is located in three dimensional space, and later calculate its distance to both faulting plane. If the hypocenter is located on one of the two plane fault, so the fault plane is the real fault plane. If the hypocenter is not located in one of the two-fault plane, the real fault plane is the closest one to the hypocenter.

Based on the analysis result using HC-plot method for 2008/05/03 event (Figure 10) it is known that the hypo-

Table 2. 1-D velocity model that is used in three components local waveform inversion.

\begin{tabular}{cccccc}
\hline Depth $(\mathbf{k m})$ & $\mathbf{V}_{\mathbf{p}}(\mathbf{k m} / \mathbf{s})$ & $\mathbf{V s}(\mathbf{k m} / \mathbf{s})$ & $\mathbf{R h o}(\mathbf{g} / \mathbf{c c})$ & $\mathbf{Q p}$ & $\mathbf{Q s}$ \\
\hline 0.0 & 2.31 & 1.300 & 2.500 & 300 & 150 \\
1.0 & 4.27 & 2.400 & 2.900 & 300 & 150 \\
2.0 & 5.52 & 3.100 & 3.000 & 300 & 150 \\
5.0 & 6.23 & 3.500 & 3.300 & 300 & 150 \\
16.0 & 6.41 & 3.600 & 3.400 & 300 & 150 \\
33.0 & 6.70 & 4.700 & 3.400 & 300 & 150 \\
\hline
\end{tabular}

Even date-time: 20080503 03:53:35

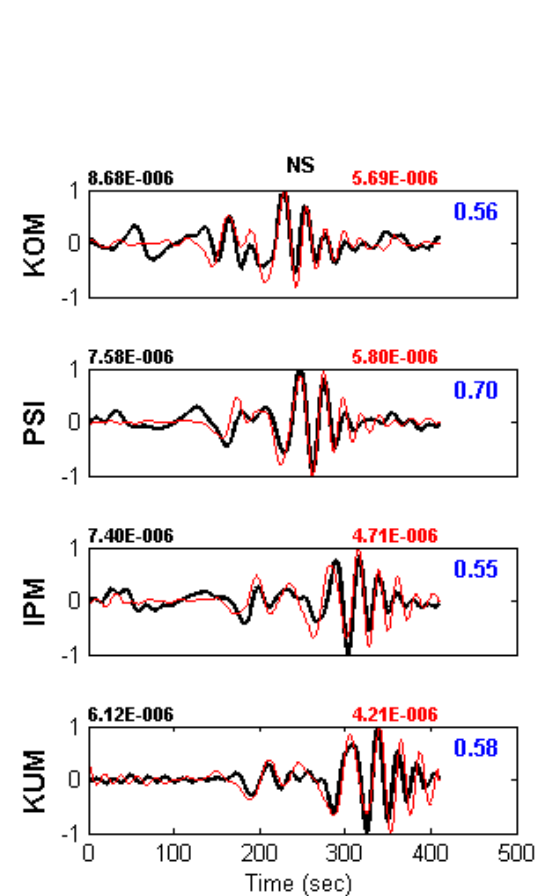

Displacement (m). Inversion band (Hz) 0.0050 .010 .050 .055

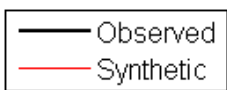

Gray waveforms weren't used in inversion.

Blue numbers are variance reduction
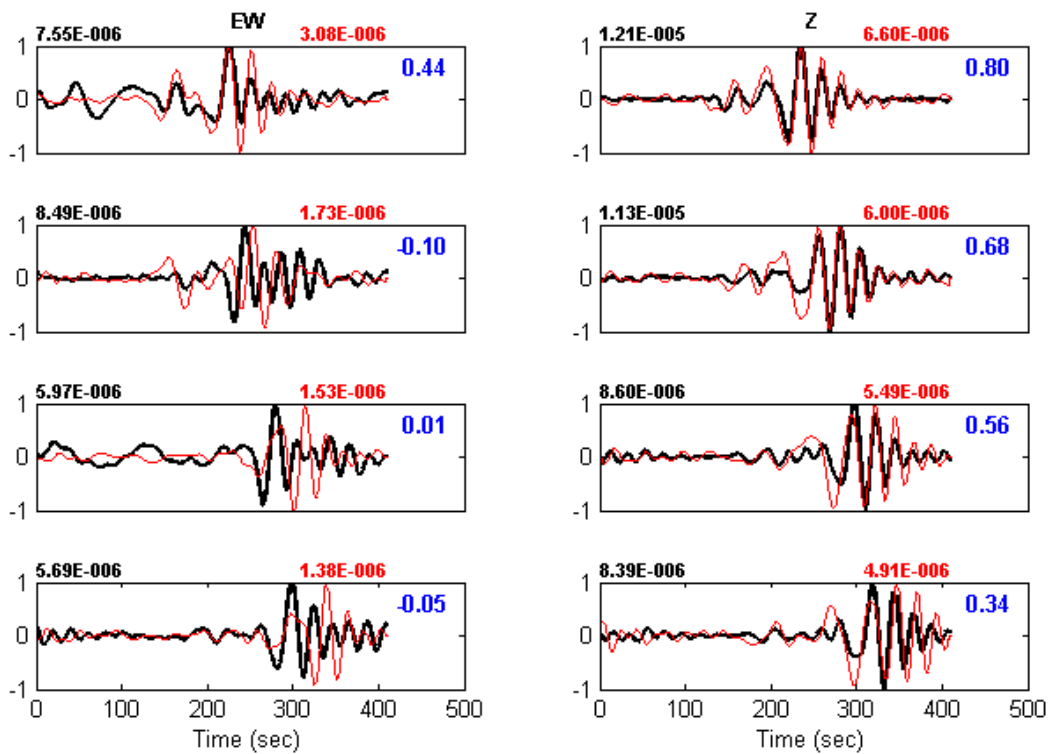

Figure 2. Components observed local waveform (black) and synthetic (red) for 2008/05/03 event. 


\section{Observed}
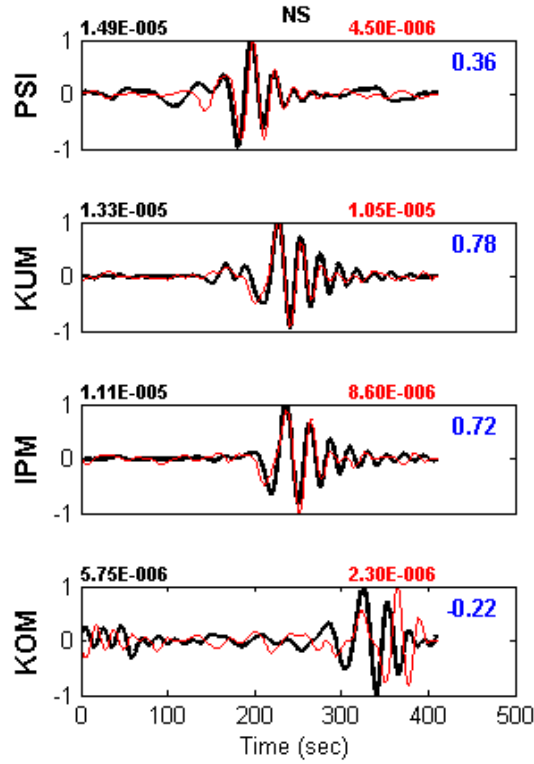
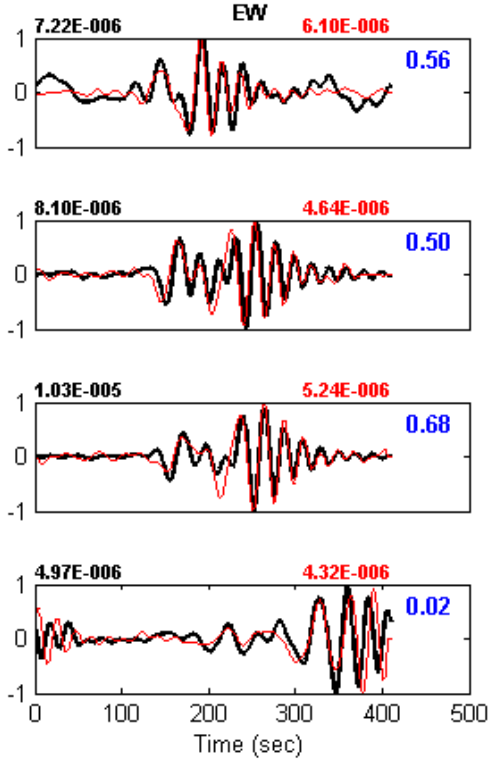

Gray waveforms weren't used in inversion.

Blue numbers are variance reduction
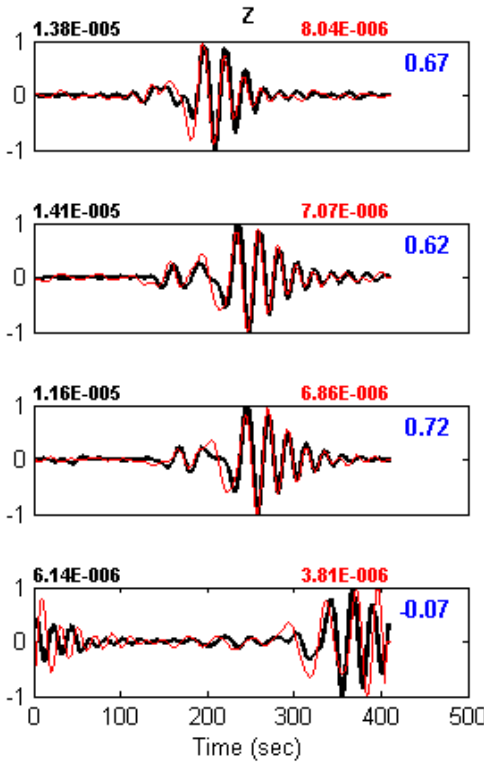

Figure 3. Components observed local waveform (black) and synthetic (red) for 2008/05/13 event.

Even date-time: 20080518 12:17:26
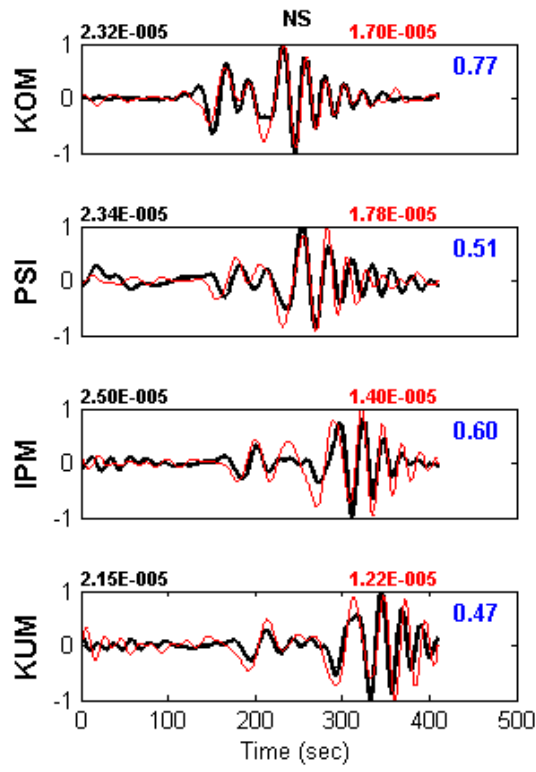

Displacement (m). Inversion band (Hz) 0.0050 .010 .050 .055

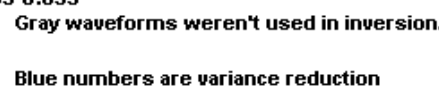

Blue numbers are variance reduction
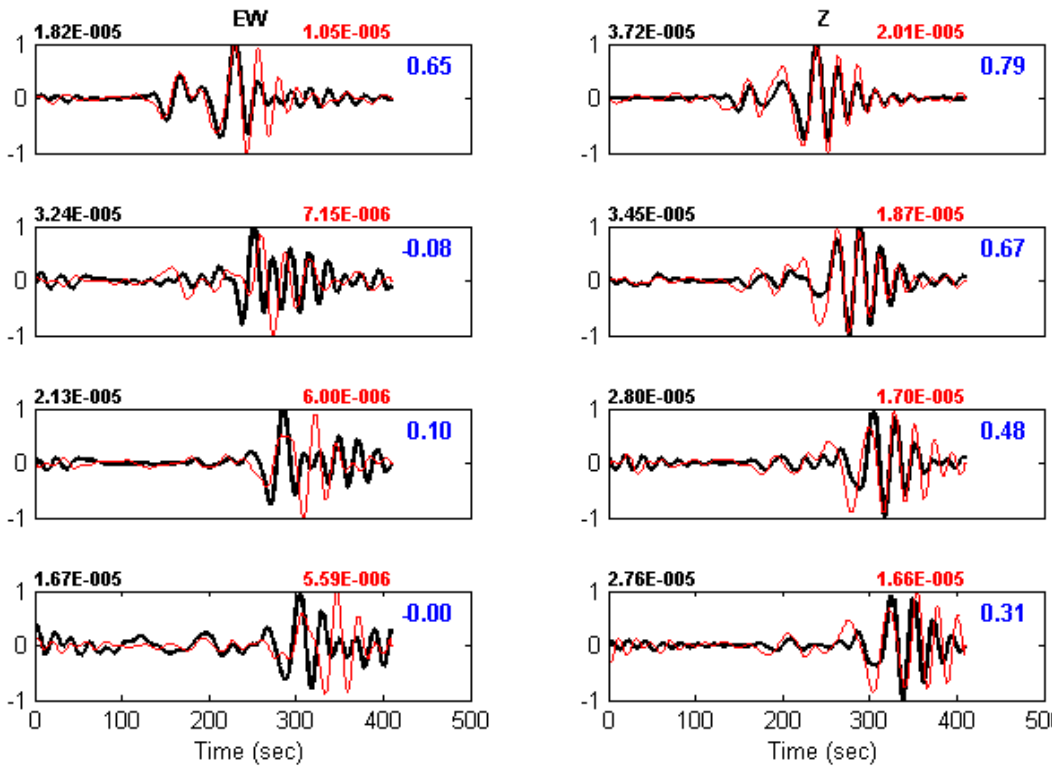

Figure 4. Components observed local waveform (black) and synthetic (red) for 2008/05/18 event.

center and centroid distance is $33 \mathrm{~km}$. While fault plane 1 shown in Figure 10 has geometry of strike $=314^{\circ}$; dip $=$ $34^{\circ}$; rake $=98^{\circ}$ (green) with a distance $4.33 \mathrm{~km}$ from hypocenter and fault plane 2 has geometry of strike $=$ $125^{\circ}$; dip $=56^{\circ} ;$ rake $=85^{\circ}$ (red) with a distance 22.02 $\mathrm{km}$ from hypocenter. The distance of fault plane 1 (green) to the hypocenter is closer than fault plane 2 (red). Therefore, the real fault plane is fault plane 1 . 
Even date-time: 20080519 14:26:46
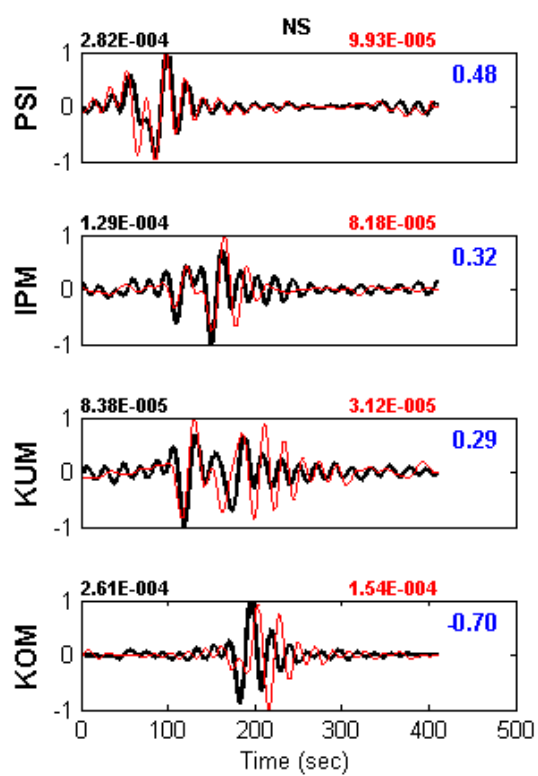

Displacement (m). Inversion band (Hz) 0.0050 .010 .050 .055

Gray waveforms weren't used in inversion. Blue numbers are variance reduction
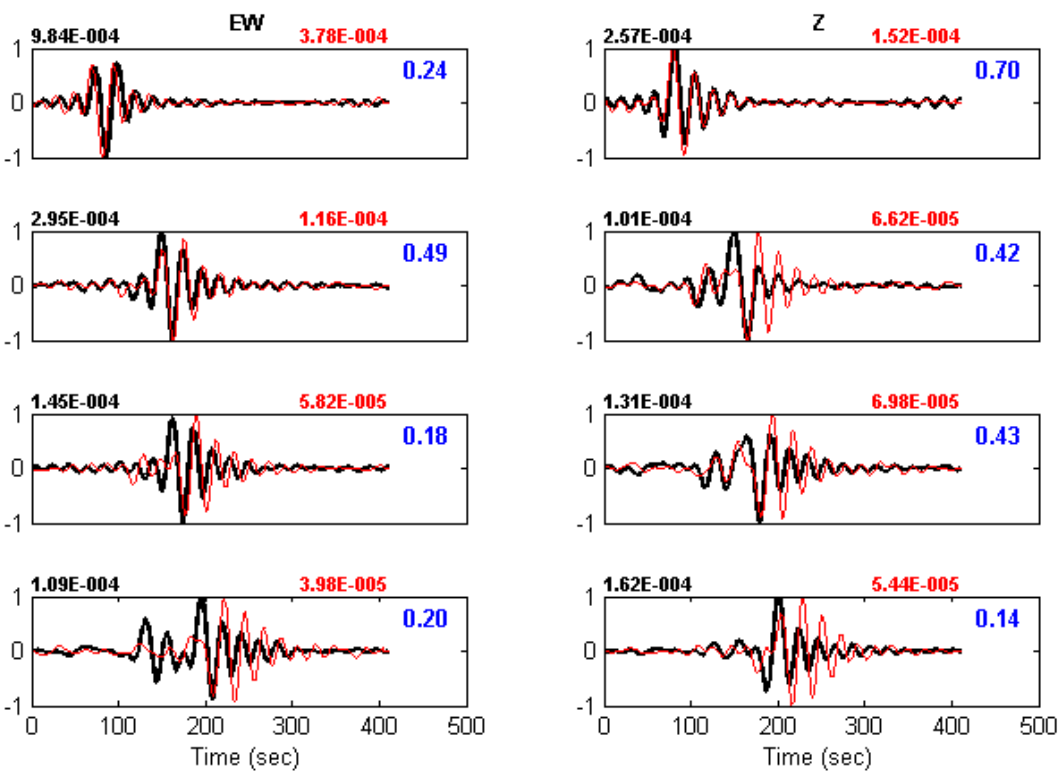

Figure 5. Components observed local waveform (black) and synthetic (red) for 2008/05/19 event.

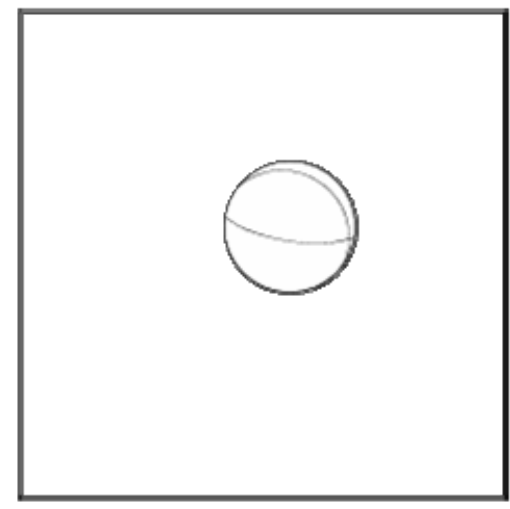

\section{MOMENT TENSOR SOLUTION}

\section{HYPOCEMTER LOCATION (WEBDC)}

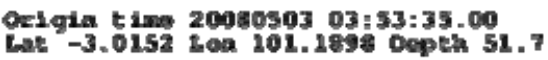

\section{CENTROID}

Trinl soares number : 15 (Fixed Bpicenter iavaralen)

Ceatrold Lat -3.9152 Coa 101.1 ses

Ceatroid Derth : 33

Cestroid time: -1.75 (sec) celative to origin tive

Nemont (Man) : 1, 594et617

$\mathrm{Kn}=\mathbf{5}$.

DCt $: 16-7$

다으 $: 23.3$

Var.red. (tor etcatioas used in Imvecsion :0.3

Var. sed. (for all stations) 10.5

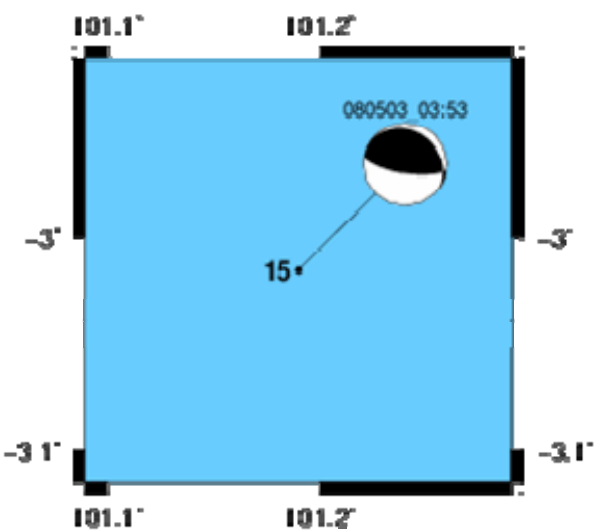

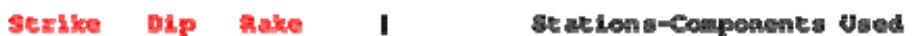

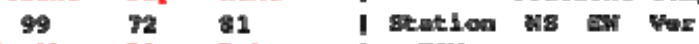

stcrlbe Dip Aabe I ncw t * t

$\begin{array}{lllll}306 & 19 & 116 & \mathrm{RgI} & +\end{array}$

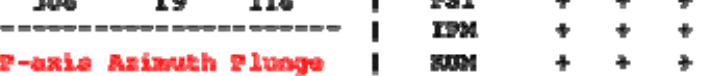

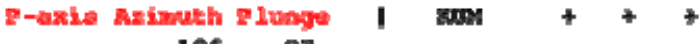

T-axts arginuth ionge

MS 196
Mrr whe Mpp

$-0.994-1.439-1.337$

Mrt Mrp kp

$0.335-6.0210 .074$

Exposuat trai: 17

Figure 6. Earthquake source parameters (CMT) 2008/05/03 event. 

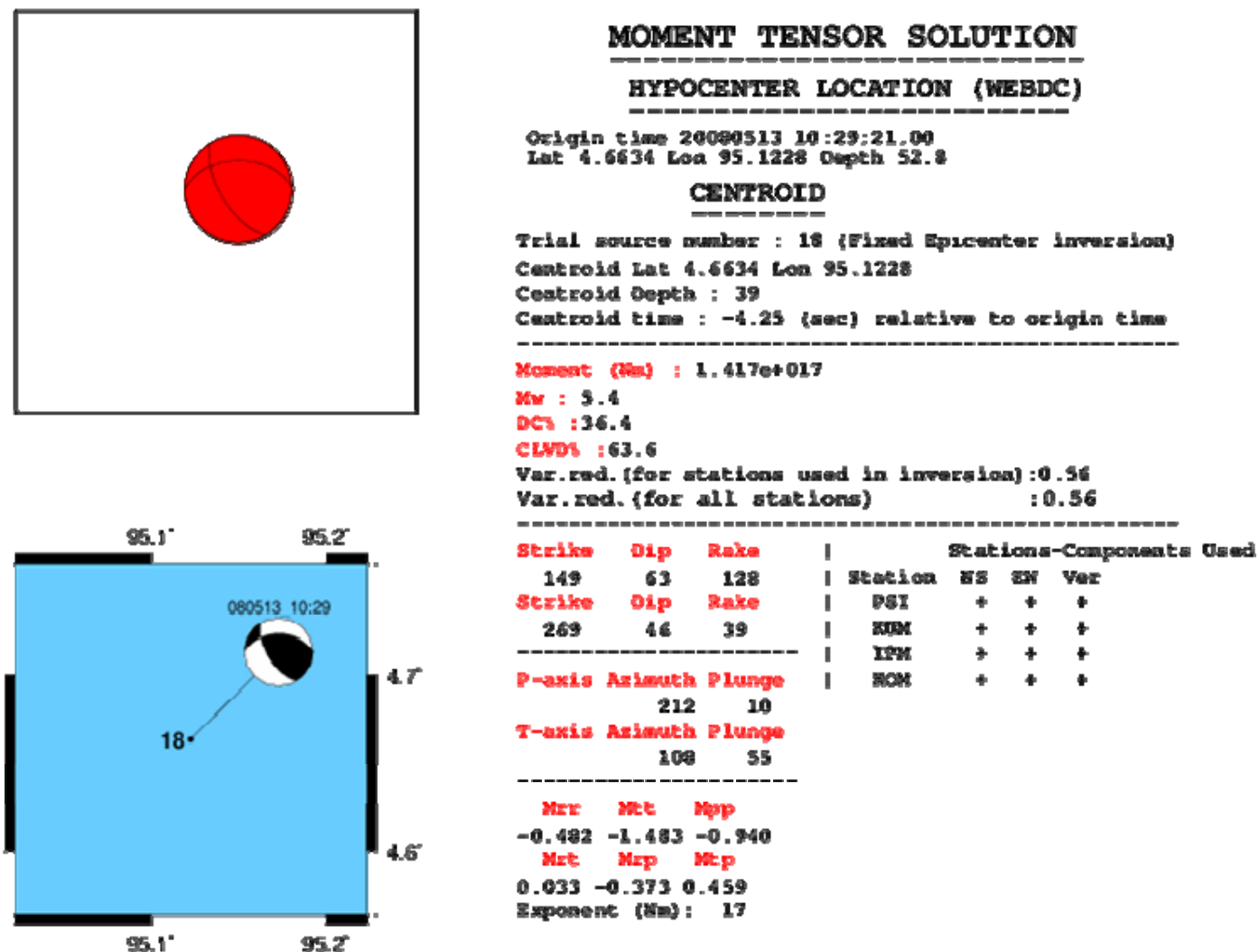

Figure 7. Earthquake source parameters (CMT) 2008/05/13 event.

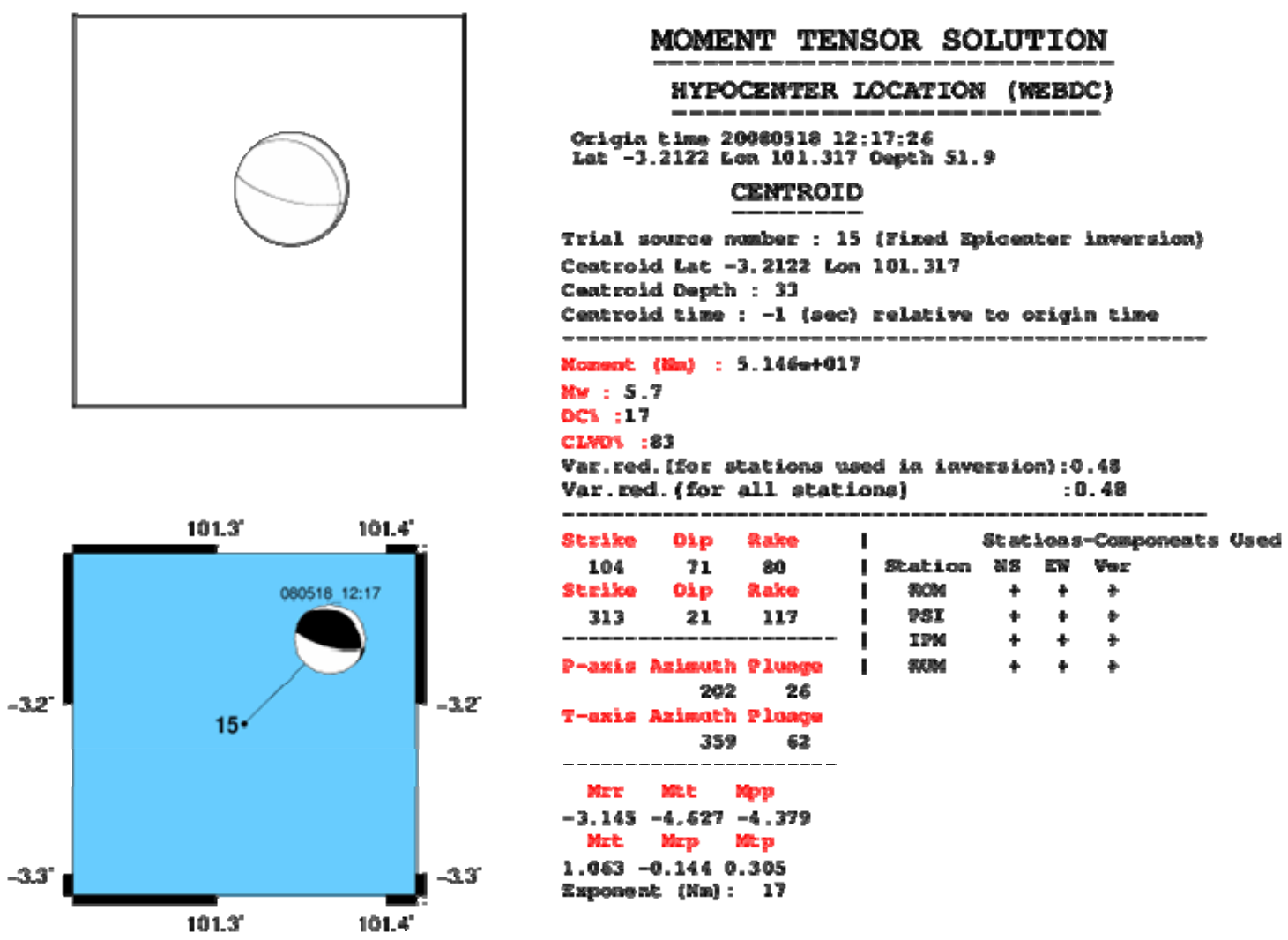

Figure 8. Earthquake source parameters (CMT) 2008/05/18 event. 

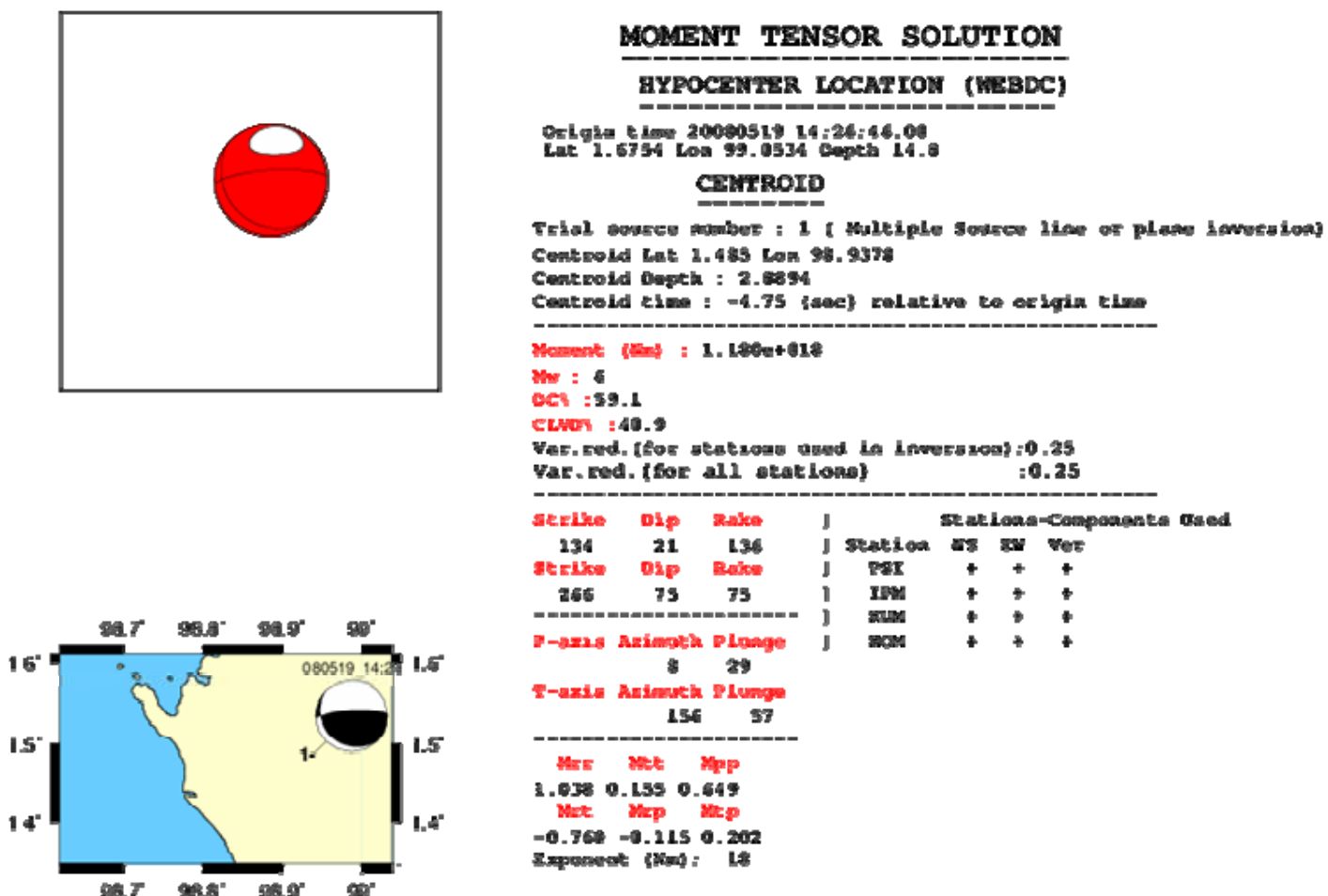

Figure 9. Earthquake source parameters (CMT) 2008/05/19 event.

The HC-plot method analysis of 2008/05/13 earthquake, illustrated in Figure 11, shows that the fault plane 1 (green, strike $=279^{\circ} ; \operatorname{dip}=29^{\circ} ;$ rake $=66^{\circ}$ ) has shorter distance to hypocenters than the auxilliary fault plane (red, strike $=126^{\circ} ; \operatorname{dip}=64^{\circ} ;$ rake $=103^{\circ}$ ), therefore the real fault plane is fault plane 1 .

The HC-plot method analysis of 2008/05/18 earthquake, illustrated in Figure 12, shows that the fault plane 1 (green, strike $=279^{\circ}$; dip $=29^{\circ} ;$ rake $=66^{\circ}$ ) has distance to hypocenter of $3.40 \mathrm{~km}$ which is shorter than the auxilliary fault plane (red, strike $=126^{\circ}$; dip $=64^{\circ}$; rake $=$ $103^{\circ}$ ) of $17.32 \mathrm{~km}$, therefore the real fault plane is fault plane 1.

The HC-plot method analysis of 2008/05/19 earthquake, illustrated in Figure 13, shows that the fault plane 1 (green, strike $=148^{\circ} ; \operatorname{dip}=60^{\circ} ;$ rake $\left.=155^{\circ}\right)$ has a distance 3.04 $\mathrm{km}$ from hypocenterand the auxilliary fault plane (red, strike $=126^{\circ} ; \operatorname{dip}=64^{\circ} ;$ rake $=103^{\circ}$ ), has a distance 8.43 $\mathrm{km}$ from hypocenter. The distance of fault plane 1 to the hypocenter is closer than fault plane 2 . Therefore, the real fault planeis fault plane 1 .

\section{Discussion}

Accurate hypocenter parameter and focal mechanism estimation can provide vital information regarding the earthquake strength and orientation of the fault plane. In this research, we used three components local broadband that is recorded by IRIS/Malaysia MY network stations and

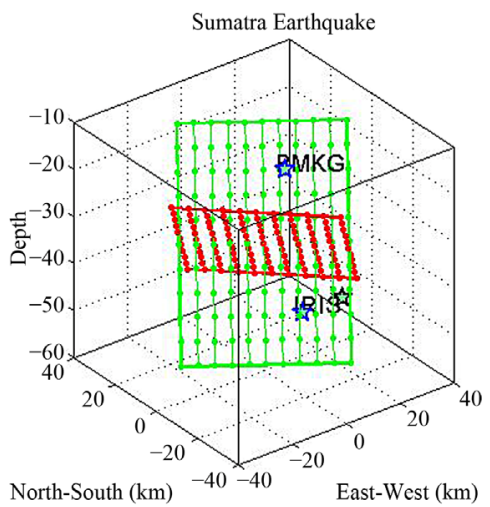

Figure 10. The distance offault plane 1 (green) is closer to the hypocenter than fault plane 2 (red) for 2008/05/03 event.

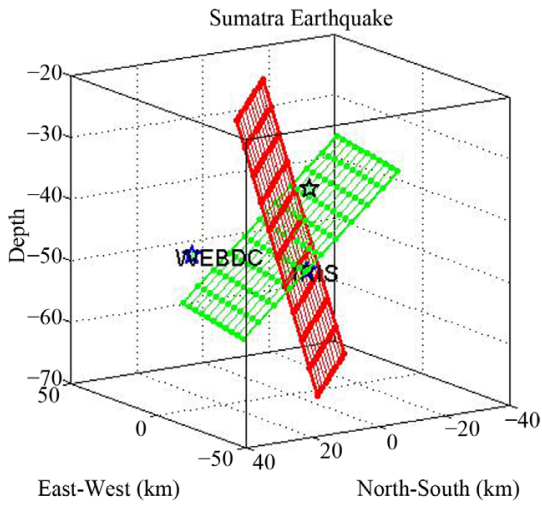

Figure 11. The distance offault plane 1 (green) is closer to the hypocenter than fault plane 2 (red) for $2008 / 05 / 13$ event. 


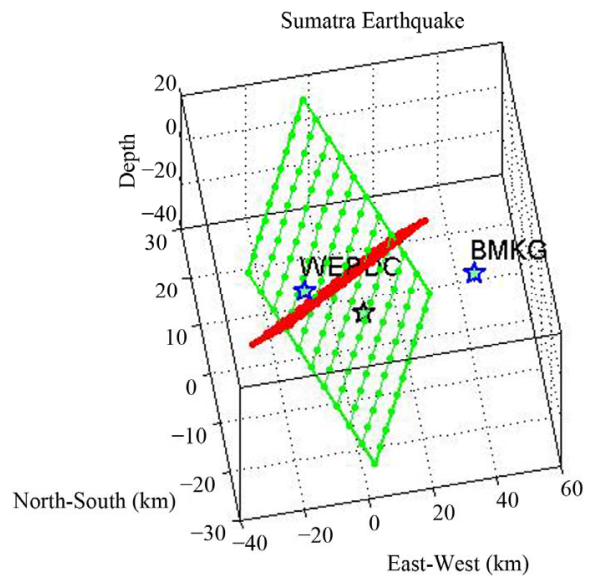

Figure 12. The distance offault plane 1 (green) is closer to the hypocenter than fault plane 2 (red) for 2008/05/18 event.

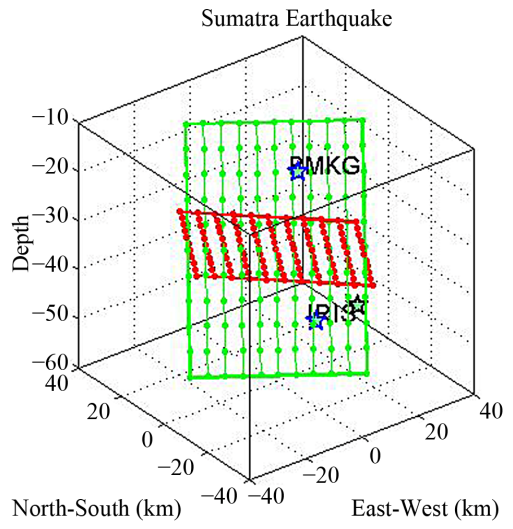

Figure 13. The distance offault plane 1 (green) is closer to the hypocenter than fault plane 2 (red) for $2008 / 05 / 19$ event.

IRIS/MS station [5]. Station code (St), distance ( $\Delta$ ), centroid depth(d), $M_{0}, M_{w}$, strike(stk), dip, rake(rak) for each events is presented in Tables 3 and 4, and the results will be compared to the GlobalCMT.

Comparison between centroid points from GlobalCMT and this research of 2008/05/18earthquake event shows the same longitude and lattitude point, and $27.4 \mathrm{~km}$ difference of the earthquake source $(50.1 \mathrm{~km}$ and $22.6 \mathrm{~km})$. Magnitude moment of this research is $5.8\left(\mathrm{M}_{\mathrm{w}}\right)$, while from GlobalCMT is $5.7\left(\mathrm{M}_{\mathrm{w}}\right)$. Detailed information can be seen in Tables 3 and 4. Parameters obtained from this research shows good seismogram fitting on three components for all stations. Faulting type of the 2008/05/18 and $2008 / 05 / 19$ earthquakes is reverse oblique with rake angles $105^{\circ}$ and $107^{\circ}$, respectively. The origin time of this result is slightly different ( +0.2 second) to the hypocenter origin time. The hypocenter location of this research is $27 \mathrm{~km}$ shallower than the one obtained from Global CMT, while the longitude and latitude position of this research and Global CMT is the same. The Magnitude moment of this research and Global CMT is slightly different $\left(\mathrm{M}_{\mathrm{w}}=\right.$ 5.7 and 6.0) and this research $\left(\mathrm{M}_{\mathrm{w}}=5.8\right.$ and 5.9) for
Table 3. Centroid Position and Earthquake source parameters of earthquakes from Author.

\begin{tabular}{cccccccccc}
\hline $\begin{array}{c}\text { Event } \\
48\end{array}$ & $\mathbf{d}(\mathbf{k m})$ & Lat & Lon & $\begin{array}{c}\mathbf{M}_{\mathbf{0}} \times \mathbf{1 0}^{\mathbf{2 4}} \\
\text { (dyne-cm) }\end{array}$ & $\mathbf{M}_{\mathbf{w}}$ & Stk & Dip Rake \\
\hline $2008 / 05 / 03$ & 32.936 & -2.8758 & 101.238 & 2.159 & 5.5 & $314^{\circ}$ & $34^{\circ}$ & $98^{\circ}$ \\
$2008 / 05 / 13$ & 44.451 & 4.504 & 95.1554 & 4.749 & 5.7 & $279^{\circ}$ & $29^{\circ}$ & $66^{\circ}$ \\
$2008 / 05 / 18$ & 22.608 & -3.1155 & 101.329 & 6.697 & 5.8 & $315^{\circ}$ & $29^{\circ}$ & 101 \\
$2008 / 05 / 19$ & 7.9631 & 1.698 & 99.0941 & 9.641 & 5.9 & $251^{\circ}$ & $68^{\circ}$ & $32^{\circ}$ \\
\hline
\end{tabular}

Table 4. Centroid Position and Earthquake source parameters of earthquakes from GlobalCMT.

\begin{tabular}{ccccccccc}
\hline $\begin{array}{c}\text { Event } \\
48\end{array}$ & d (km) & Lat & Lon & $\begin{array}{c}\mathbf{M}_{(\mathbf{d}} \times \mathbf{1 0}^{\mathbf{2 4}} \\
\text { (yne-cm) }\end{array}$ & $\mathbf{M}_{\mathbf{w}}$ & Stk & Dip Rake \\
\hline $2008 / 05 / 18$ & 50.1 & -3.52 & 101.11 & 1 & 5.7 & $321^{\circ}$ & $29^{\circ}$ & $105^{\circ}$ \\
$2008 / 05 / 13$ & 16.1 & 1.64 & 99.14 & 1 & 6.0 & $331^{\circ}$ & $82^{\circ}$ & $173^{\circ}$ \\
\hline
\end{tabular}

20080518 and 20080519 earthquakes. The fault type of these research is reversed oblique with rake $105^{\circ}$ and $173^{\circ}, \mathrm{M}_{\mathrm{w}}=5.7$ and 6.0. The origin timeof this research is slightly different $(+0.2$ second) to the hypocenter origin time.

\section{Conclusion}

Earthquake parameters of three events (seismic moment, magnitude moment and fault plane orientation) are extracted after fitting between measured and synthetic seismogram is achieved with the reduction variants of all events are over $56 \%$. Using HC_plot method, we can identify the real fault plane for these events. The fault type of each event is reverse oblique. The result of this research is different with Global CMT in which all components of moment tensor are compared.

\section{Acknowledgements}

We would like to express our gratitude to those who help us to finish this research. We want to thank the GFZPostdam Geofon-Jerman and BMKG-Indonesia that gave us permission to download the waveform data recorded by IA network stations. We have furthermore to thank Prof. Dr. Zahradnik and Dr. Efthimios Sokos that give us guidance in understanding ISOLA-GUI and HC-plot softwares and also apply the softwares to estimate earthquake [15] source parameters using three-dimension local waveform

(http://seismo.geology.upatras.gr/isola). We are deeply indebted to Prof. Dr. Toda, S., Prof. Dr. R. S. Stein, Prof. Dr. P. A. Reasenberg, Prof. Dr. J. H. Dieterich, dan Prof. Dr. A. Yoshida that allow us and give guidance in estimating the length and width of fault plane block and also slip length using Coulomb3.109 software

(http://quake.wr.usgs.gov/research/deformation/modeling /home/swf). 


\section{REFERENCES}

[1] S. Lasitha, M. Radhakrishna and T. D. Sanu, "Seismically Active Deformation in the Sumatra-Java Trench-Arc Region: Geodynamic Implications," Current Science, Vol. 90, No. 5, 2006, pp. 690-696.

[2] D. H. Natawidjaya, "Neotectonics of the Sumatra Fault and Paleogeodesy of the Sumatra Subduction Zone," Thesis, California Institute of Technology, Pasadena, 2002.

[3] K. R. Newcomb and W. R. McCann, "Seismic History and Seismotectonics of the Sunda Arc," Journal of Geophysical Research: Solid Earth, Vol. 92, No. B1, 1999, pp. 421-439.

[4] L. Prawirodirdjo, Y. Bocl, R. McCaffrey, J. Genrich, E. Calais, C. Stevens, S. S. O. Puntodewo, C. Subarya, J. Rais, P. Zwick and R. M. Fauzi, "Geodetic Observations of Interseismic Strain Segmentation at the Sumatra Subduction Zone," Geophysical Research Letters, Vol. 24, No. 21, 1997, pp. 2601-2604. doi:10.1029/97GL52691

[5] Toda, S., R. S. Stein, P. A. Reasenberg, J. H. Dieterich and A. Yoshida, "Stress Transferred by the $1995 M_{\mathrm{W}}=$ 6.9 Kobe, Japan, Shock: Effect on Aftershocks and Future Earthquake Probabilities," Journal of Geophysical Research, Vol. 103, No. B10, 1998, pp. 24543-24565.

[6] K. Madlazim, B. J. Santosa and U. Widya, "ParameterParameter Sumber Gempa Bumi Padang dan Korelasinyadengan Gempa Bumi-Gempa Bumi Berikutnya, Prosiding Seminar Nasional Fisikadan Aplikasinya, ITS," ITS, Surabaya, 2009.

[7] B. N. Joewono, "1.117 Orang Meninggal akibat Gempa Padang,” 2009. http://regional.kompas.com/read/xml/2009/10/15/102351 6/1.117.orang.meninggal.akibat.gempa.padang

[8] O. Novotný, J. Zahradník and G.-A. Tselentis, "NorthWestern Turkey Earthquakes and the Crustal Structure Inferred from Surface Waves Observed in the Corinth Gulf, Greece," Bulletin of the Seismological Society of America, Vol. 91, No. 4, 2001, pp. 875-879.

[9] B. J. Santosa, "Analyzing the Seismogram of Earthquakes on Sumatra-Java Subduction Plane at CHTO Observation Station,” Journal MIPA, Vol. 13, 2008, pp. 13-21.

[10] M. Kikuchi and H. Kanamori, "Inversion of Complex Body Waves-III," Bulletin of the Seismological Society of America, Vol. 81, No. 6, 1991, pp. 2335-2350.

[11] E. N. Sokos and J. Zahradnik, "ISOLA a Fortran Code and a Matlab GUI to Perform Multiple-Point Source Inversion of Seismic Data," Computers \& Geosciences, Vol. 34, No. 8, 2008, pp. 967-977.

[12] J. Zahradnik and E. Sokos, "ISOLA-GUI: A Matlab GUI for Moment Tensor Retrieval," 2009.

[13] J. Zahradnik, A. Serpetsidaki, E. Sokos and G.-A. Tselentis, "Iterative Deconvolution of Regional Waveforms and a Double-Event Interpretation of the Lefkada Earthquake, Greece," 2006. http://seismo.geology.upatras.gr/isola/

[14] O. Coutant, "Program of Numerical Simulation AXITRA, in Research Report," LGIT, Grenoble, 1989.

[15] J. Zahradnik, F. Gallovic, E. Sokos, A. Serpetsidaki and G.-A. Tselentis, "Quick Fault-Plane Identification by a Geometrical Method: Application to the $\mathrm{M}_{\mathrm{w}} 6.2$ Leonidio Earthquake, 6 January 2008, Greece," Seismological Research Letters, Vol. 79, No. 5, 2008, pp. 653-662. 